\title{
ПСИХОЛОГІя
}

DOI https://doi.org/10.32405/2522-9931-2021-16(45)-10-24

UDC: $159.922 ; 159.922 .7 / .8$

\section{Shahnaz Guliyeva,}

Lecturer of the Sumgayit State University;

Assoc. professor of Department of Pedagogy and Psychology.

Sumgayit, Azerbaijan.

ORCID ID: https://orcid.org/0000-0001-9311-3888

shahnaz1969@mail.ru

\section{PSYCHOLOGICAL ISSUES OF INFLUENCE OF AGGRESSIVE BEHAVIOR ON INTERPERSONAL RELATIONSHIPS OF YOUNG PEOPLE}

\begin{abstract}
In the article is to reasrch the psychological reasons for the impact of aggressive behavior on interpersonal relationships of young people in modern period. This problem is actual in several point of view. The problem has not been explored in the psychological aspect, since «aggression» was initially viewed as a medical, biological, and hereditary category. In second, if we approch to this problem in general psychological aspect, it will clear that aggression is not considered as a process. Simply touching the emotional targets and needs of a person is episodic. Thirdly while explaining the general psychological mechanisms of aggressive behavior, attention has not been paid to the ethnic-national factors of its manifestation. Finally, the formation and manifestation of aggressive behavior directly into the subject of research enables us to explore the broadest details of this behavior. The role of the family in the family formation process is also menthioned in the article. Parents play an important role in shaping the concept of «I», awareness and thinking, interests and needs, as well as the care and attention given to the child in the family. In this regard, interpersonal relations play a special role in the socialization of youth. Inadequate family relationships, neglect of the interests and needs of young people in the family, a parental approach to the desires and desires of young people from the prism of their own interests and needs play a minor role in creating stress, anxiety and depression in young people. The most important reason for the development of aggressive behavior in young people and their impact on interpersonal relationships in society is that parents do not communicate properly with their children since childhood, which is a psychological and children's family dispute. Agressive behavior was spread among young
\end{abstract}



https://doi.org/10.32405/2522-9931-2021-16(45)

generation and it get growth. Such young people destroy the society with their values and attitudes to. Such young people undermine their values and attitudes to society. Selfishness, indifference and negative behavior are typical of such young people. We came to a conclusion that the causes of youth aggression as a result of physiological changes in the body. The biological, psychological and sociological factors are the reasons for the aggressive behavior of young people. The phenomenon of aggression in young people can be influenced by both situational factors, which may arise from a desire to avenge or to compensate, which is also reflected in the article.

Keywords: youth; aggression; behavior; socialization; anger; violence; loss; attack.

\section{INTRODUCTION / ВСТУП / ВВЕДЕНИЕ}

Formulation of the problem. In the modern era, the formation of the younger generation as a comprehensive personality is one of the major problems facing both society and psychology. From the moment of birth, the young generation enters into the life of the society, they are socialized and have its own stage of development. One of the main problems in the development of youth identity in the modern era is the study of the psychological causes of the impact of aggressive behavior on interpersonal relationships, which is relevant for several reasons. The problem has not been explored in the psychological aspect, since «aggression» was initially viewed as a medical, biological, and hereditary category. Second, from the general psychological aspect, it becomes clear that aggression is not considered as a process. Simply touching the emotional states and needs of a person is episodic. Third, while explaining the general psychological mechanisms of aggressive behavior, attention has not been paid to the ethnic-national factors of its manifestation. Finally, the formation and manifestation of aggressive behavior directly into the subject of research will allow us to investigate the broadest details of this behavior.

Due to our theme, it is important to note that the role of family in the formation of youth identity is indispensable. The interpersonal relationships, attention and care in the process of socialization of young people have their own psychological effects. Parents play an important role in shaping the concept of «I», awareness and thinking, interests and needs, along with the care and attention that is given to the child in the family. In this regard, interpersonal relationships play a special role in the socialization of young people. Inadequate intra-family relationships, neglect of the interests and needs of young people in the family, and parents' approach to the desires and desires of young people 
from the prism of their own interests and needs play little role in creating the tension and excitement in the youth.

Analysis of the latest relevant research and publications. This topic has been researched by many authors before the relevant research. These works were examined before the research and some of them were referred to. The cited works are: B. Aliev, R. Jabbar «The identity issue in education» [1], R. Aliyev «Psychology of upbringing» [2], R. Aliyev «Psychology» [3], R. Aliyev, G. Aliyeva «Personality Psychology» [4], A. Bayramov «Social Psychology» [5], A. Bayramov, A. Alizade «Psychology» [6], A. Bayramov «Talking about youth and self-education» [7], A. Bakhshaliyev «Development of psychological disorders in Azerbaijan» [8].

\section{AIM AND TASKS / МЕTA ТА ЗАВДАННЯ / ЦЕЛИ И ЗАДАЧИ}

The main objective of the article is to reasrch the psychological reasons for the impact of aggressive behavior on interpersonal relationships of young people in modern period.

For this purpose, the article sets the following tasks:

- the main task of the article is to study the psychological causes of the impact of aggressive behavior on relationships in young people and to identify ways and means to eliminate them.

- clarification of the characteristics of the formation and manifestation of aggressive behavior and the general psychological mechanisms of aggressive behavior is one of the main psychological tasks in the formation of young people as a comprehensive personality in modern times, and this problem is widely reflected in the article.

\section{THE THEORETICAL BACKGROUNDS / TEOPETИЧHI ОСНОВИ} ДОСЛІДЖЕННЯ / ТЕОРЕТИЧЕСКИЕ ОСНОВЫ ИССЛЕДОВАНИЯ

This problem is actual in several point of view. The problem has not been explored in the psychological aspect, since «aggression» was initially viewed as a medical, biological, and hereditary category. In second, if we approch to this problem in general psychological aspect, it will clear that aggression is not considered as a process. Simply touching the emotional targets and needs of a person is episodic. Thirdly while explaining the general psychological mechanisms of aggressive behavior, attention has not been paid to the ethnicnational factors of its manifestation. Finally, the formation and manifestation of aggressive behavior directly into the subject of research enables us to explore the broadest details of this behavior. The role of the family in the family formation process is also menthioned in the article. 


\section{RESEARCH METHODS / МЕTОДИ ДОСЛІДЖЕННЯ / МЕТОДЫ ИССЛЕДОВАНИЯ}

This analysis was conducted with the study of the sources related to the subject, the analysis of the results obtained, the analysis and synthesis of the arguments, and also the comparative analysis method.

\section{RESEARCH RESULTS / РЕЗУЛЬТАТИ ДОСЛІДЖЕННЯ / РЕЗУЛЬТАТЫ ИССЛЕДОВАНИЯ}

The most important reason for the development of aggressive behavior in young people and their impact on interpersonal relationships in society is the fact that parents have been unable to communicate properly since childhood, and that child abuse and family disputes as a psychological cause are controversial. The most common cause of violence in youth interactions is their aggressive depression. As aggression is, as we have noted, children begin to form at an early age. Violence against children in the family is also a major problem. In the future, this child will become an adult and begin to apply what he sees, thus aggravating the situation in society. The relationship between parents and family conflicts has a serious impact on children. Every person's psychology has traces of their environment. If a young child has experienced more psychological stress, then that depression is more common in that young person.

In the family, physical violence and lack of proper relationships create negative feelings for parents, themselves, and their peers. Aggressive behavior is widespread among young people in the modern era and is getting more and more popular. In aggressive young people, egotism, neglect of their surroundings, and negative behaviors are more typical of some of their typical features. The biological, psychological and sociological factors are the reasons for the aggressive behavior of young people. The phenomenon of aggression in young people can be influenced by both situational factors and the desire to avenge or to compensate. Aggression (lat. Aggredi means «to attack») - the desire of one living being to cause harm to another living being, either physically or mentally. In young people, aggression can occur in two ways: 1) For the purpose of enmity, to hurt someone, 2) To achieve the goal - Instrumental. The following are the causes of aggression in the behavior of young people:

1. Inflammation in the brain can lead to problems such as aggression. Medicine is usefull in such situation;

2. How the young man does not know how to use their energy;

3. The aggressive observation of the young man: his parent can be a friend, a relative or a television hero.

Observations show that television programs, in addition to family 
relationships, play a major role in revealing aggressive behavior in young people from an early age.

Therefore, television programs that are watched by a child from an early age should be monitored, and parents must comment on the child's aggressive scenes and emphasize that they should not affect the child's mind and thinking and behavior. One of the reasons for escalation of domestic conflicts and tensions among young people in general is financial problems. Financial constraints are a contributing factor to family dissatisfaction. As a result, aggression is manifested in the inability to meet the needs of young people, which also affects their relationship [1, p. 306].

When a young person does not get what he wants, he begins to act aggressively toward himself and those around him. Fatigue, tense work schedules, educational and work failures also aggravate young people. Also, the foods we eat can also cause depression and depression in young people. Special attention is paid to the somatic problem as the first cause of aggressive behavior in young people. Observations show that the anxiety caused by some diseases in the body is caused by negative emotional activity. As a result, young people are reluctant to comply with the demands and assignments of their parents and teachers, thus manifesting themselves in interpersonal relationships in the form of aggression. The second reason is direct mental illness: neurosis, schizophrenia, autism, hyperactivity, and so on. The third reason is sociopsychological and pedagogical problems. These problems include age crises, breakdowns of relationships with older people and peers, and interpersonal and interpersonal conflicts. It should be noted that, depending on the psychosocial characteristics, the aggressive behavior of young people is manifested differently.

Purpose. Aggregation management in the regulation of mutual relations in young people. It has become clear that the execution of an aggressive act is a deterrent to the aggressor's subsequent action. Unfortunately, not all socially acceptable forms of prevention in young people reduce the level of aggression. The reason for this is the presence of strong stimulus to prevent aggression that cannot be coerced with violence. Compassion, mercy, humor, interest in cooperation, apologies, etc. aggressive tendencies such as these are significantly weakened. Psychologists have developed effective measures to manage aggression in the regulation of reciprocal interactions with social norms.

They are:

1) Modeling - demonstrating different models for achieving goals without the use of aggression; 
2) Role-playing - feedback, appreciation of non-aggressive behavior models, practical application of acquired habits in real conditions;

3) Aggression in young people is caused by a number of unpleasant factors, such as social and material problems, gaps in family upbringing from an early age, neglect of personal and psychological traits in the family and school, brain disorders, brain disorders, and so on. can be shown.

When dealing with aggressive youth, the following specific rules of behavior should be observed:

1. One of the key psychological factors that focuses on the calm reaction of young people during the aggression is their attention.

If aggressive behavior is not dangerous and understands, the following positive strategies can be used: behaviors;

- Ignoring aggressive behavior is a powerful way to avoid unpleasant

- statement expressin your understanding of the youth ( Of course, it affects you...»);

- to direct attention to another object or issue.

Young people often use aggression to draw attention to themselves.

2. The focus should be on the behavior of the young person, not on his personality, but on the behavior of the young person. How he behaved during the aggression, it is necessary to describe words and actions.

One of the main factors to note is that young people do not remember their past actions in order to be critical of their behavior.

3. Parents or teachers should monitor their negative emotions when communicating with aggressive youth. Aggressive behavior of young people is a strong negative emotion in adults - irritability, anger and resentment. it creates fear and despair. Adults should accept this negative and normal.

Adults manage their negative emotions to prevent aggravating the aggressive situation created by a young person.

4. Prevention of tension. The main task of adults during the aggression of youth is to reduce the tension. Increasing adult voices, threatening the child, demonstrating power, shouting, insulting, aggressive gestures, using physical force, attracting strangers to the conflict, punishing the young, comparing the pressure with the good guys. Although the situation has calmed down for a while, all these reactions have a more negative effect on the young psychologically.

5. The behavior of the young person should be discussed not after depression but after calm. The wrong actions of a young man should never be discussed by others, and should not be overlooked. 
6. One of the main ways to prevent aggressive behavior in young people is to demonstrate non-aggressive behavior. The parent should carefully listen to the teenager without analyzing it. He should be able to fully explain his point.

The problem of aggressive and auto-aggressive behavior in young people plays an important role in the life of every society. Despite numerous efforts to integrate this problem into the framework of social psychology, its medical aspects cannot be overlooked. First, there are hypotheses that consider the role of biological factors in the formation of auto and hetero-depression. Second, aggressive and auto-aggressive behaviors are often associated with clinical manifestations of mental disorders. Almost every day we receive information in the media about crimes, wars, acts of terrorism, which are the embodiment of the aggressive behavior of young people. Speaking of the medical aspects of aggression, it is primarily about mental aggression. Thus, in many cases, any behavior that is harmful or harmful to others is regarded as aggression. Sometimes, aggression is considered as a product of the emotional sphere [1, p. 5].

Observations show that underlying the aggressive behavior of young people are emotional - such as hate and anger. Attempts to link aggression to motivation do not seem convincing either. Finally, it is not always possible to assess aggression from the point of view of cognitive processes (hostility, hostility). In many cases, aggression is directed toward those close to those who are well-nourished and positive. It seems expedient to use the multiclassification of aggressive behavior given by Buss (1976). Under this scheme, aggressive actions are described in 3 lines (axis): physical-verbal, active-passive, direct-indirect. The question of what effects young people have on aggressive behavior - whether endogenous or environmental - has not been fully resolved. Most likely, each of these factors contributes to some or other aggressive behavior. Aggressive behavior, according to Lorenz's hypothesis, depends on specific external factors that provide or brake the accumulated aggressive energy. It is also important to note that the ability to restrain their aggressive instincts has to do with the possibility of seriously injuring victims. Explaining the nature of aggression from his instinct, Freud concluded in the 1920s that man had a special instinctive tendency to destroy and destroy life. From then, aggression is divided into benign and malignant types. The first is the aggression of the game, which is more common in sports.

The goal here is not to kill or injure your opponent, but to show courage and skill. Another type of benevolent aggression is self-propensity towards the goal. Such aggression is essential for a young business manager, brilliant politician, courageous researcher to achieve his goals and self-assertion. Of 
course, the defensive tendency to protect life rather than to destroy it is also related to benevolent aggression. The aggressive forms of youth aggression include aggression caused by jealousy and jealousy. In this case, the young man is not only capable of acquiring what he wants, but also committing acts of violence because he has someone else. Another type of aggression is aggression with the aim of revenge. Unlike defense aggression, damage is no longer a protection, and it does not have a protective function. He is trying to bring back what has already happened. This is far more than the reality. There is also a depression in the young people regarding the shaking of confidence. From: «Loss of self-confidence leads to hatred». Finally, the most extreme form of aggression is compensatory aggression. Compensatory aggression is characteristic of young people who lack the ability to detect positive forces. They take revenge on the world for lacking the opportunity to live a full life. His logic is consistent with the formula «If I cannot create, I must destroy».

The goal here is not to kill or injure your opponent, but to show courage and skill. Another type of benevolent aggression is self-propensity towards the goal. Such aggression is essential for a young business manager, brilliant politician, courageous researcher to achieve his goals and self-assertion. Of course, the defensive tendency to protect life rather than to destroy it is also related to benevolent aggression. The aggressive forms of youth aggression include aggression caused by jealousy and jealousy. In this case, the young man is not only capable of acquiring what he wants, but also committing acts of violence because he has someone else. Another type of aggression is aggression with the aim of revenge. Unlike defense aggression, damage is no longer a protection, and it does not have a protective function. He is trying to bring back what has already happened. This is far more than the reality. There is also a depression in the young people regarding the shaking of confidence. From: «Loss of self-confidence leads to hatred». Finally, the most extreme form of aggression is compensatory aggression. Compensatory aggression is characteristic of young people who lack the ability to detect positive forces. They take revenge on the world for lacking the opportunity to live a full life. His logic is consistent with the formula «If I cannot create, I must destroy».

Different tests are often used to identify latent aggression - thematic appraisal tests (TAT), Rorschark's spots test, and Roensweig's drawing test for the study of frustration. The study of the motivation for aggressive behavior is the most controversial area. From this perspective, when studying aggression, the following types of motivations can be shown: 1) Perceptual motives are actions aimed at achieving a specific goal. This includes aggression aimed at protecting yourself and those around you, obtaining material gain, and 
concealing crime. 2) Undiscovered (psychodynamic) motives - compressed, unrealized ideas, various complexes, imperfect defense mechanisms. Such aggressive motivation is more common in young psychopaths, sadists, and sex offenders. 3) Psychotic motivations - are common in other clinical practice. Aggression is associated with mental disorders (for example, intoxication and organic psychosis), perceptual and mental disorders (eg during schizophrenia) [6, p. 2].

Aggression as the object of research is biology, etology, sociology, law, conflictology, etc. is also learned by scientists. However, it is psychologists who conduct research on the nature of the person's aggressive behavior, the nature of such feelings, their manifestations in behavior, and their causes. Foreign scientists Leonard Berkowicz, Deborah Richardson, Robert Beron, Arnold Bass, Albert Bandura, Neil Miller, Stanley Milgram, John Dollard, Zigmont Freud, Conrad Lawrence, Christian Butler and many others. We find the views and opinions of Russian psychologists on the problem of A. Rean, L. Semenyuk, L. Ivanov, T. Rumyantseva, Anna Ros and others. In Azerbaijan, the medical aspects of aggression were developed by N. Ismayilov and F. Ismayilov. From personal traits that cause aggression in young people, we should note the following: 1) Emotional deficit - not to be pessimistic about others, not to be distressed, to ignore people's feelings and needs; 2) The prejudice signs of aggression are when a young person embodies his or her negative emotional goals; 3) Pathological irritation - immediate reaction of a young person to even the slightest provocative factor. Such young people quickly disengage and choose more aggressive forms of behavior in a conflict situation; 4) Internnality is the belief that a young person can influence the course of events in any situation [4, p. 8]. According to research, internal youth consider aggression as a means to achieve their desired goal. 5) Embarrassment - implies a negative evaluation of the self-esteem («I» or «me») of the young person. Although it may seem strange, often embarrassed youths display a sense of resentment and hostility toward those who are "guilty» when they feel humiliated. Important information has been obtained from the study of Megharji, who studies the relationship between self-control and aggression. The researcher, who has observed extreme forms of violence, has come to a surprising conclusion that the most terrible crimes are those who always appear inactive, patient and restrained. They are called aggressors who have too much control over them. There are a number of factors in depressed young people who can handle aggression or, conversely, those who do not possess this trait. From this point of view, youth's attitude to life, the system of moral values, social relations, personal and collective self-importance are important [7, p. 3]. Economic factors 
play a major role in the formation of aggressive behavior in young people. Numerous studies confirm that violent acts are more prevalent among the lower social strata of the population. Poverty, illiteracy, and unemployment make young people less likely to achieve their goals, and tend to aggravate aggression. The timely detection of psychiatric disorders related to dangerous forms of behavior, and treatment, significantly reduces the risk of psychiatric patients committing aggressive behavior. Alcohol and drugs also cause aggressive behavior.

Observations show that the intensity of aggression with outsiders depends on: a) how aggressors assess the attitudes of outsiders; b) Observer's social status (for example, whether that person has the authority to command or prevent the aggression); Another group of factors - cultural factors - may also be included here. In this context, let us consider three systems of ethnic structure described by E. Fromu in the formation of aggressive behavior. In the first system, hostility and cruelty are very rare. There is no specificity or tendency to compete. Instead, mutual aid, trust relations, and legal equality prevail. The second system is a moderately aggressive society. The prevalence of peculiarity, serious hierarchy, economic success and physical health is widespread [6, p. 2].

The third system is characterized by hostility, enmity, destructive tendencies, mutual distrust, suspicion, and fear among members of society. Thus, the reaction to the manifestations of aggression is quite different. Unfortunately, many societies still experience racial and ethnic aggression, and this is reflected in the behavior of the younger generation. Aggression is often found among representatives of subcultural types, preferring non-traditional practices, such as a number of youth groups (bikers, metallists, football fans) or those living in criminogenic environments. In such an environment, it is common for brutality to be socially accepted, even commendable. Cultural factors influencing aggressive behavior include media, movies and computer games, which are widely used in modern mass cultures. A number of experiments have shown that aggression tendencies have been strengthened after watching films rich in violence [2, p. 6].

It is assumed that the influence of the media occurs through the activation of specific memories and emotions in memory. Erotic and pornographic materials, which are a product of modern culture, have the potential to increase the tendency of aggression in both men and women. 


\section{CONCLUSIONS AND PROSPECTS FOR FURTHER RESEARCH / ВИСНОВКИ ТА ПЕРСПЕКТИВИ ПОДАЛЬШИХ ДОСЛІДЖЕНЬ / ВЫВОДЫ И ПЕРСПЕКТИВЫ ДАЛЬНЕЙШИХ ИССЛЕДОВАНИЙ}

The most common method of preventing and managing aggression in young people is not properly punished. However, observations show that possible punishment can only prevent aggression in young people under appropriate conditions. If the potential aggressors are in a state of extreme anger, the threat of punishment is usually ignored by them. If the profits from violent work outweigh the fear of punishment, punishment will not be able to control the aggression. Lastly, the punishment should be severe enough to prevent aggression, and the likelihood of its application is high. The penalties imposed can be prevented by further aggressive manifestations, provided that the period between aggressive action and punishment is short. Otherwise the cause-and-effect relationship is broken. The penalty imposed must be commensurate with the degree of aggressive behavior.

Impunity creates a sense of impunity when punishment is not severe enough. Extremely severe punishment is regarded as unfair and gives rise to future aggression. In addition, it is important for the aggressor to understand that certain forms of behavior are constantly subjected to punishment. Another direction for managing aggression is catharsis - the ability to express one's anger and anger in a socially acceptable form. It has become clear that the execution of an aggressive act is a deterrent to the aggressor's subsequent action. Unfortunately, not all socially acceptable forms of prevention reduce the degree of aggression. The use of non-aggressive behavior models is considered more appropriate. Demonstration of restraint, patience, the ability to resolve challenges, constructively resolve conflicts and maintain one's self-ethical standards are no less influenced by youth than aggressive behavior. Being aware of any mitigating factor also prevents young people's aggressive reactions. For example, if we see that our partner's aggression is related to problems that are not of our concern, we are less concerned about his anger. A powerful way to prevent aggression is to have impulsive stimuli that do not coexist. Compassion, mercy, humor, interest in cooperation, apologies, etc. aggressive tendencies such as these are significantly weakened.

Prospect for futher research. The most honest research method of aggressive behavior in young people is to observe them under normal circumstances. Observing the conflict between young people and their peers and family members provides interesting material to explore the causes of aggression. When studying aggression in young people, a number of aspects need to be considered. First, as a neutral observer, it is very difficult to watch 
events from the outside while displaying the aggression. second, observations of this kind are subjective and depend on the observer's assessment of any behavior as an expression of aggression.

\section{REFERENCES / СПИСОК ВИКОРИСТАНИХ ДЖЕРЕЛ / СПИСОК ЛИТЕРАТУРЫ (TRANSLATED AND TRANSLITERATED)}

[1] B. H. Aliev, R. V. Jabbar, The identity project in education. Baku, Azerbaijan: Education, 2008, $134 \mathrm{p}$.

[2] R. I. Aliyev, Psychology of upbringing. Baku, Azerbaijan: Nurlan, 2006, $200 \mathrm{p}$.

[3] R. I. Aliyev, Psychology. Baku, Azerbaijan: Nurlan, 2008, 352 p.

[4] R. I. Aliyev, G. B. Aliyeva, Personality Psychology. Baku, Azerbaijan: ADPU Press, 2010, 144 p.

[5] A. S. Bayramov, Social psychology. Baku, Azerbaijan: Qapp-Printing Corporation, 2003, 306 p.

[6] A. S. Bayramov, A. A. Alizade, Psychology. Baku, Azerbaijan: Qapp-Printing Corporation, 2002, $540 \mathrm{p}$.

[7] A. S. Bayramov, Talking about youth and self-education. Baku, Azerbaijan: Youth, 1969, $136 \mathrm{p}$.

[8] A. T. Bakhshaliyev, Development of psychological disorders in Azerbaijan. Baku, Azerbaijan: Maarif, 1991, p. 292.

\section{ПСИХОЛОГІЧНІ ПИТАННЯ ВПЛИВУ АГРЕСИВНОЇ ПОВЕДІНКИ НА МІЖОСОБИСТІСНІ ВІДНОСИНИ МОЛОДІ}

\section{Гулиева Шахназ Мустафа,}

кандидат психологічних наук,

доцент кафедри педагогіки і психології

Сумгаїтського державного університету.

Сумгаїт, Азербайджан.

ORCID İ: https://orcid.org/0000-0001-9311-3888

shahnaz1969@mail.ru

Анотація. У статті досліджуються психологічні причини впливу агресивної поведінки на міжособистісні стосунки молоді у сучасний період. Ця проблема актуальна 3 різного погляду. Проблема не досліджувалась у психологічному аспекті, оскільки спочатку «агресія» розглядалася як медична, біологічна та спадкова категорія. По-друге, якщо ми підійдемо до цієї проблеми у загальному психологічному аспекті, то стане ясно, що агресія не розглядається як процес. 
Торкатися емоційних цілей та потреб людини є епізодичним. По-третє, у процесі пояснення загальних психологічних механізмів агресивної поведінки не зверталася увага на етнічно-національні фактори іï прояву. Нарешті, формування та прояв агресивної поведінки безпосередньо у предметі дослідження дозволяє нам дослідити найширші деталі цієї поведінки. У статті також зазначено роль сім'ї у процесі формування. Батьки відіграють важливу роль у формуванні поняття «Я», усвідомлення та мислення, інтересів та потреб, а також турботи та уваги, що надаються дитині у сім'ї. У зв'язку з цим міжособистісні стосунки відіграють особливу роль у соціалізації молоді. Неадекватні сімейні стосунки, нехтування інтересами та потребами молоді у сім'ї, батьківський підхід до бажань та бажань молоді з призми власних інтересів та потреб відіграють незначну роль у створенні стресу, тривоги та депресії. Найважливішою причиною розвитку агресивної поведінки у молоді та їх впливу на міжособистісні стосунки у суспільстві $\epsilon$ те, що батьки з дитинства не спілкуються належним чином зі своїми дітьми, що $є$ психологічною та дитячою сімейною суперечкою. Агресивна поведінка була поширена серед молодого покоління, і воно набуває зростання. Така молодь руйнує суспільство своїми цінностями та ставленням. Молодь підриває їхні цінності та ставлення до суспільства. Егоїзм, байдужість та негативна поведінка характерні для таких молодих людей. Ми дійшли висновку, що причини молодіжної агресії в результаті фізіологічних змін в організмі. Біологічні, психологічні та соціологічні фактори $\epsilon$ причинами агресивної поведінки молодих людей. На явище агресії у молоді можуть впливати обидва ситуативні фактори, які виникають унаслідок бажання помститися, що також відображено у статті.

Ключові слова: молодь; агресія; поведінку; соціалізація; гнів; насильство; втрата; напад.

\section{ПСИХОЛОГИЧЕСКИЕ ВОПРОСЫ ВЛИЯНИЯ АГРЕССИВНОГО ПОВЕДЕНИЯ НА МЕЖЛИЧНОСТНЫЕ ОТНОШЕНИЯ МОЛОДЕЖИ}

\section{Гулиева Шахназ Мустафа,}

кандидат психологических наук,

доцент кафедры педагогики и психологии

Сумгаитского государственного университета.

Сумгаит, Азербайджан.

ORCID ID: https://orcid.org/0000-0001-9311-3888

shahnaz1969@mail.ru 
Аннотация В статье исследуются психологические причины влияния агрессивного поведения на межличностные отношения молодых людей в современный период. Эта проблема актуальна с нескольких точек зрения. Проблема не исследовалась в психологическом аспекте, поскольку сначала «агрессия» рассматривалась как медицинская, биологическая и наследственная категория. Во-вторых, если мы подойдем к этой проблеме в общем психологическом аспекте, то станет ясно, что агрессия не рассматривается как процесс. Просто касаться эмоциональных целей и потребностей человека является эпизодическим. В-третьих, при объяснении общих психологических механизмов агрессивного поведения не обращалась внимание на этнически-национальные факторы ее проявления. Наконец, формирование и проявление агрессивного поведения непосредственно в предмете исследования позволяет нам исследовать широкие детали этого поведения. В статье также отмечается роль семьи в процессе формирования семьи. Родители играют важную роль в формировании понятия «Я», осознание и мышления, интересов и потребностей, а также заботы и внимания, предоставляемых ребенку в семье. В связи с этим межличностные отношения играют особую роль в социализации молодежи. Неадекватные семейные отношения, пренебрежение интересами и потребностями молодых людей в семье, родительский подход к желаниям и желаний молодых людей $с$ призмы собственных интересов и потребностей играют незначительную роль в создании стресса, тревоги и депрессии у молодых Люди. Важнейшей причиной развития агрессивного поведения у молодых людей и их влияния на межличностные отношения в обществе является то, что родители с детства не общаются должным образом со своими детьми, является психологической и детской семейной спором. Агрессивное поведение было распространено среди молодого поколения, и оно приобретает роста. Такая молодежь разрушает общество своими ценностями и отношением. Такая молодежь подрывает их ценности и отношение к обществу. Эгоизм, равнодушие и негативное поведение характерные для таких молодых людей. Мы пришли к выводу, что причины молодежной агрессии в результате физиологических изменений в организме. Биологические, психологические и социологические факторы являются причинами агрессивного поведения молодых людей. На явление агрессии у молодежи могут влиять оба ситуативные 
факторы, которые могут возникать вследствие желания отомстить или компенсировать, что также отражено в статье.

Ключевые слова: молодость; агрессия; поведение; социализация; гнев насилие; потеря; нападение.

\section{REFERENCES (TRANSLATED AND TRANSLITERATED)}

[1] B. H. Aliev, R. V. Jabbar, The identity project in education. Baku, Azerbaijan: Education, 2008, 134 p.

[2] R. I. Aliyev, Psychology of upbringing. Baku, Azerbaijan: Nurlan, 2006, $200 \mathrm{p}$.

[3] R. I. Aliyev, Psychology. Baku, Azerbaijan: Nurlan, 2008, 352 p.

[4] R. I. Aliyev, G. B. Aliyeva, Personality Psychology. Baku, Azerbaijan: ADPU Press, 2010, 144 p.

[5] A. S. Bayramov, Social psychology. Baku, Azerbaijan: Qapp-Printing Corporation, 2003, $306 \mathrm{p}$.

[6] A. S. Bayramov, A. A. Alizade, Psychology. Baku, Azerbaijan: Qapp-Printing Corporation, 2002, $540 \mathrm{p}$.

[7] A. S. Bayramov, Talking about youth and self-education. Baku, Azerbaijan: Youth, 1969, $136 \mathrm{p}$.

[8] A. T. Bakhshaliyev, Development of psychological disorders in Azerbaijan. Baku, Azerbaijan: Maarif, 1991, p. 292. 